\title{
RETIFICAÇÃO NECESSÁRIA
}

No volume 217 da RDA figurou artigo subscrito por Julio Cezar da Silva sobre " $R e$ forma Administrativa e a terceirização do setor público".

Em carta recebida de ALICE GONZALEZ BORGES foi, por ela dito, que, no referido artigo constam trechos que são cópia literal de trabalho seu, sem indicação da fonte, como se fossem do autor do artigo.

Assim o título 2.4.6, na pág. 24 da RDA representam cópia literal de trechos do estudo da missivista constante de seu ensaio publi- cado na coletânea “ Nova dimensão - Direito Administrativo - edição NDJ - vol. I/1997".

E, ainda, nas páginas 28 e 29 do referido artigo, repete o mesmo empréstimo não confessado, das páginas 39 a 41 do ensaio de Alice Gonzalez Borges na publicação citada.

Não tendo conseguido localizar o autor do artigo incriminado, para melhor esclarecimento, registramos, com pesar, a ocorrência, que não poderia ter sido previamente identificada pela redação da $\mathrm{RDA}$. 